\title{
Bridging Activism and the Academy: Exposing Environmental Injustices Through the Feminist Ethnographic Method of Photovoice ${ }^{1}$
}

\author{
Shannon Elizabeth Bell ${ }^{2}$ \\ Department of Sociology, University of Kentucky, Lexington, \\ United States
}

\section{Abstract}

The neoliberal rejection of a strong role for governmental regulation of industry has led to increasingly negative consequences for the environment and the people who are forced to bear a disproportionate share of the health and safety hazards created by corporate polluters. The voices of the victims of environmental injustice often go unheard in the policy arena, while an arsenal of paid industry lobbyists exerts undue influence and power over legislative and regulatory agency processes. In this paper, I argue that we as social scientists are frequently positioned in such a way that we could serve as links between the people we study and policymakers, providing an avenue for exposing the ways that neoliberal policies negatively affect the health, safety, and well-being of disenfranchised groups. Through presenting a "Photovoice" project I conducted with 54 women living in five coal-mining communities in southern West Virginia, I demonstrate how feminist activist ethnography, as a distinct type of activist research, can be used for social science inquiry while simultaneously providing an opportunity for research participants' stories to be heard — and acted upon - by those with political power.

Keywords: activist research, coal, environmental justice, feminist ethnography, neoliberalism, photovoice

\section{Introduction}

According to the United States Environmental Protection Agency's Toxics Release Inventory, in 2009 alone, United States industries self-reported releasing 3.37 billion pounds of toxic pollutants into the air, water, and land. Of these

\footnotetext{
1 An earlier version of this article received the 2013 Robert Boguslaw Award for Technology and Humanism from the Environment \& Technology Section of the American Sociological Association.

2 Author contact: shannon.eliz.bell@gmail.com.
} 
toxic substances, approximately 700 million pounds are known or suspected carcinogens (EPA, 2009). Because these are self-reported numbers, it is impossible to know how many more millions of pounds of released toxics are not reported.

The cause of such high rates of illegal releases can be traced to both a lack of enforcement of the laws that are in place and an overall inadequacy of pollution regulation. As a case in point, an investigative study conducted by The New York Times in 2009 reveals that since the passage of the Clean Water Act of 1977, the rate of water pollution violations has risen significantly. Between 2004 and 2009, companies and other facilities self-reported violating the Clean Water Act more than 506,000 times (Duhigg, 2009). The vast majority of these polluters have escaped punishment; less than 3 percent of these Clean Water Act violations led to fines or other sanctions for the offending companies (Duhigg, 2009).

Pollution is, quite simply, a cost-saving measure, especially when regulation is lax and punishments are minimal. Over the past three decades, corporations have worked hard to reverse many of the environmental regulations that were won during the 1970s (Faber, 2008). Particularly with the increased international competition that has been the result of globalization, corporations have even more aggressively sought to lower their production costs through pushing for neoliberal policies that would reduce taxes and decrease government regulation. As a result, since the 1970s, the global economy has experienced a shift toward social and economic policies that favor the interests of capital over the wellbeing of most people. Central to this neoliberal demand for "regulatory reform" is a rolling back of policies aimed at protecting the environment and public health, occupational health and safety rules, consumer protection laws, "and other regulations seen as impinging on corporate earnings" (Faber, 2008, p. 15). Under the guise of increased "market freedom," this turn toward neoliberalism has served to strengthen the power and control of economic elites (Harvey, 2005).

Because an unrelenting drive to increase profits and decrease costs is intrinsic to corporate capitalism (Sweezy, 1989), it is standard operating procedure for companies to externalize costs (such as pollution) whenever possible (Brulle \& Pellow, 2006; Schnaiberg, 1980). It is widely held among environmental sociologists that capitalism has created a "treadmill of production" (Schnaiberg, 1980; Gould et al., 2004) or a "treadmill of accumulation" (Foster, 2005; Foster et al., 2010), wherein economic growth is dependent upon increasing the consumption of natural resources and externalizing the costs of pollution. Companies choose to pollute - both legally and illegally — because it is profitable to do so, far more profitable than implementing pollution-prevention technology (Faber, 2008). For example, rather than "internalize" the $\$ 10$ million it would take to install a scrubber to clean chemical pollutants from emissions, when 
given the choice, most chemical companies will instead choose to externalize this cost onto the surrounding community through polluting the air and damaging the health of residents (Faber, 2008; p. 24).

Arguably, neoliberal policies have caused the treadmill of accumulation to speed up. Fewer regulations and the primacy of "the market" above all else have meant that corporations have been able to externalize pollution costs more and more readily. Furthermore, as environmental justice scholars contend, not all people share the burden of these cost externalizations equally. Those with the least political and economic power-communities of color, low income communities, women, and people of the global South-bear a disproportionate share of society's waste and pollution (Bullard, 1990; Bullard et al., 2007; Čapek, 1993; Faber, 2008, 2009; Masterson-Allen \& Brown, 1990; Pellow, 2004, 2007). As Faber (2008, p. 25) so poignantly asserts, the most disempowered people in the United States are not only "effectively denied a voice in American society," but they also "serve as the dumping ground for capital."

How can we as environmental social scientists help mitigate these injustices? Does our power to counter the harmful effects of the current political-economic order lie simply in our ability to empirically study and theorize the consequences of neoliberalism and capitalism? While such examinations are certainly important to this aim, are the products of our research enough? In this paper, I contend that scholars not only have the ability to choose to study the devastating consequences of neoliberal policies on the lives of individual people, but we also hold the power to expose and attract public and policy attention to these consequences through the methods of investigation we employ.

Specifically, I contend that feminist activist ethnography - as a distinct type of activist research - is particularly well suited to act as a form of resistance to the injustices of neoliberalism. Discussions of the value of feminist methods rarely take place outside the confines of gender-related research. However, I argue that feminist activist ethnography has utility for other subfields and among scholars who may not necessarily identify as feminists. Drawing on the experience of an eight-month "Photovoice" project I conducted with 54 women living in five coal-mining communities in Central Appalachia, I discuss the ways in which feminist activist ethnography can simultaneously be used for social science inquiry while also serving to promote social justice in the wake of neoliberalism.

\section{Neoliberalism's lockdown on democratic participation}

Ironically, while neoliberal ideologues purport the "freedom" of neoliberal policies, neoliberalism is, as Barbara Ellen Smith (2014) argues, actually a regime 
of "spatial dispossession," which both "produces and depends on the lockdown of public space" (Smith, 2011, p. 5). Reid and Taylor (2010, p. 40) similarly argue that neoliberalism has closed off access to the "ecological commons" for many people, "enclos[ing] more and more life forms that were previously taboo or invisible to exchange value (water, air, forests, gift economies or care, genetic codes, professional research, etc.)." Indeed, at its very core, "The power and wealth of capitalism is predicated on the denial and erasure of the commons" (ibid.).

The political assault on the ecological commons is being initiated and led by the biggest corporate polluters in the United States, who have created an intricate web of think tanks, policy institutes, research centers, foundations, non-profit organizations, public relations firms, and political action committees that are organized with the purpose of waging war on environmental regulations (Faber, 2008 , p. 15). This network, which Faber terms the "polluter-industrial complex," is "committed to discrediting the environmental movement and to dismantling state programs and policies that promote environmental justice, protect public health, and safeguard the earth" (ibid.).

The polluting corporate power elite is able to wield inordinate influence through employing a number of strategies, such as contributing enormous sums of money to political campaigns and political action committees (Faber, 2008; Jenkins, 2011); influencing regulatory agency leadership appointments and oversight (Faber, 2008; Harrison, 2011); acting as informal "advisors" to political leaders (Switzer, 1997); hiring researchers and enlisting think tanks to obfuscate and cast doubt on incriminating scientific findings (Markowitz \& Rosner, 2002; McCright \& Dunlap, 2000; Oreskes \& Conway, 2010); reshaping public opinion through astroturf (fake grassroots) organizations and front groups (Beder, 1998; Bell \& York, 2010; Boudet \& Bell, 2014; Faber, 2008; McNutt \& Boland, 2007; Switzer, 1997); and through pouring millions of dollars into lobbying efforts (Faber, 2008; Jenkins, 2011; Switzer, 1997). According to Faber (2008), this final tactic - special interest lobbying - is a particularly powerful mechanism for “colonizing the state." In 2009 and 2010, special interests spent nearly \$7 billion on lobbying (Beckel, 2011), and there are approximately 90,000 people engaged in or supporting lobbying activities in Washington, DC alone (Faber, 2008, p. 97). As Faber argues:

The infusion of such enormous sums of money into the lobbying process buys corporate polluters disproportionate access to governmental officials and exerts a corrosive effect on American democracy. Industry lobbyists are now integrated so extensively into the environmental agency rule-making and legislative processes that their recommendations 
are frequently adopted with little modification. In some cases, corporate lobbyists are the ones actually writing the new rules and regulations word for word. (Faber, 2008, p. 98)

Thus, most often, the voices of ordinary citizens are left out of the legislative process entirely. If neoliberalism is a regime of "spatial dispossession" (Smith, 2014), one of the most insidious sites of spatial dispossession is democratic participation. Accessing and providing input into public policy is a nearly impossible task for the average citizen. As Reid and Taylor (2010) assert, the political system discourages - even blocks - true democratic participation and civic engagement. Individuals must practically "bushwhack their own way out of their homes in order to connect their personal paths with others" and navigate the policy arena (Reid \& Taylor, 2010, p. 81). Furthermore, the people who are the most affected by neoliberal policies tend to have the least political power and fewest resources, such as time, money, and education. Thus, a lack of power and resources often translates to a lower propensity toward mobilizing against the machinations of the polluter-industrial complex.

The control that the polluter-industrial complex exerts over the legislative and regulatory bodies that are tasked with protecting the health of the public and environment is clearly a malfeasance of tremendous magnitude. But even more, undoing this lockdown on democratic space may be critical for the future of our planet and its inhabitants. Numerous scholars have argued that in order to slow down the devastation wrought by the treadmill of accumulation, control of the federal government must be wrested away from the polluter-industrial complex and put into the hands of local people (Faber, 2008; Foster, 2009; Reid \& Taylor, 2010).

Democratizing the state is a monumental task. However, we as social scientists are positioned in such a way that we can contribute to this purpose if we so choose, and I contend that feminist activist ethnography is particularly well suited for this aim.

\section{Feminist activist ethnography: Exposing the effects of neoliberalism on individual lives}

Ethnography can be described as a "cocktail" of methods that "share the assumption that personal engagement with the subject is the key to understanding a particular culture or social setting" (Hobbs, 2006, p. 101). This "cocktail" of methods can include such components as participant observation, interviews, discourse analysis, photographs, and other artifacts of the social world (Hobbs, 2006). What makes an ethnography explicitly feminist is when it incorporates an intentionality to expose the structures of power that lead to inequality and the 
oppression of certain groups, through highlighting the "everyday experiences" of those individuals who are "forced to live on the margins" of society (Davis, 2013, p. 27). As Craven and Davis (2013, p. 1) define it, feminist ethnography is a "project committed to documenting lived experience as it is impacted by gender, race, class, sexuality, and other aspects of participants' lives." The mission of feminist inquiry, as articulated by Stanley (1990, p. 15), "is to change the world, not only to study it."

An ethnography becomes activist when it incorporates an "intervention" of some form that works toward social justice goals (Davis, 2013, p. 27). Thus, what makes feminist activist ethnography distinct as a research method is (1) its emphasis on revealing the lived experiences of social inequality and injustice among research participants, and (2) its attempt to do something to bring about positive social change for the people in the study.

Certainly, feminist activist ethnography is not the only type of social science research that is aimed at intervening on behalf of social justice. Practitioners of liberation sociology (Feagin \& Vera, 2008); participatory action research (FalsBorda, 1987; McIntyre, 2008; Tandon, 1981); public sociology (Agger, 2000; Burawoy, 2005); public anthropology (Borofsky, 2011); and activist critical geography (Hay, 2001) also engage research strategies that seek to expose and address social injustices. However, what makes feminist activist ethnography such a powerful tool and counter to neoliberal ideology is its attention to individual people's stories and experiences of injustice. As Davis and Craven (2011) argue, neoliberalism functions to wipe away the differences among individuals in society by falsely claiming that all groups have the same access to various benefits such as health care, a living wage, a healthy environment, and democratic participation. The particularities of disenfranchised groups' experiences have been erased by neoliberalism, experiences that feminist ethnography — as a rule - privileges. As Anglin (2013, p. 46) asserts, feminist ethnography can reveal the myriad consequences of neoliberal policies, "and, in so doing, disrupt the logics of necessity and evenhandedness that serve as their justification." Feminist ethnography has the capacity to serve as a corrective to neoliberal denials of the inequalities inherent to capitalism through its power to "raise the volume of subjugated voices" and expose the ways in which neoliberal policies "lurk in people's lives" (Davis \& Craven, 2011, pp. 197, 195). In other words, researchers engaging this approach are positioned in such a way that they can, if they so choose, bring the voices of marginalized individuals forward to the policy arena.

As Bickham-Mendez (2008) asserts, consciously conducting research with the goal of packaging our findings for legislators and others with political power puts our own position of privilege to good use, as there is a tendency for decisionmakers to assume research conducted by social justice organizations is not as 
scientific or accurate as academic studies. As such, academic research has the potential to provide social justice movements credibility in the eyes of decisionmakers and to draw attention to our research subjects' narratives of injustice. The value of lending legitimacy in this way is underscored by Reid and Taylor (2010, p. 82), who point out that movements for social and environmental justice are often "dismissed as 'too local,' as mere NIMBYism." Likewise, Barbara Ellen Smith argues that there is often a "disparagement of place-based organizing as "merely' local" because the local is seen as "small, bounded, insular, interior, whereas the global represents a boundless, cosmopolitan exteriority" that is somehow more worthwhile and meaningful (Smith, 2011, p. 12; Smith \& Fisher, 2012).

Despite power-holders' frequent dismissal of "the local," I would argue that it is precisely the localness of grassroots struggles for environmental justice that offers opportunities for powerful resistance to neoliberalism. The environmental justice platform can be especially influential because it is grounded in local struggles for human rights, seeking social justice for people who live in the most polluted environments in the world. This focus on protecting people and communities makes it possible for environmental justice movements to cross political boundaries more readily than mainstream environmental movements, allowing for a wider base of support (Bell, 2010). Finding ways to expose and draw attention to locally produced narratives of injustice is something that feminist researchers are well positioned to do.

\section{The non-neutrality of feminist ethnography}

Feminist research does not claim to be neutral, and this lack of neutrality has brought it under critique from researchers who embrace a positivist approach to scientific inquiry. Positivist social science purports "value neutrality" as a litmus test for whether a research study is scientifically sound. The underlying assumption is that researcher-as-human (with a distinct gender identification, class background, age, racial and ethnic identity, sexual identity, and nationality) can, and should, be separated from the knowledge he or she produces. Researchers should be "objective" so as to create value-neutral science. Thus, the idea of undertaking a research study with the intention of exposing the injustices of neoliberalism on individual people's lives would be viewed as "unscientific" through the positivist lens. However, feminist standpoint theorists, such as Dorothy Smith and Sandra Harding, among many others, call into question the very attainability of a value-neutral science, arguing that all researchers occupy a distinct social location that influences every aspect of the knowledge-production process, including who is included as part of the research team, how the data are collected and interpreted, when and why the research project ends, how the research results are reported and shared with 
the world, and what types of questions are considered worthy of study in the first place (Harding, 1993). Sandra Harding's (1991, p. 142) concept of "strong objectivity" calls for the "acknowledgement that all human beliefs-including our best scientific beliefs - are socially situated." Thus, rather than feigning true objectivity, we, as scientists, should make clear our positionality and the biases that we inevitably bring to the table. In this way, feminist activist research can be considered a more honest science, because the views of the researcher are exposed for all to see. Taking it even a step further, Leacock (1987, p. 323) argues that attempting to conduct research as a "neutral" observer "means to align oneself, by default, with the institutional structures that discriminate and exploit poor and non-white people." Similarly, Hale (2008, p. 8 cited in Craven and Davis, 2012) contends that such attempts at neutrality create a "smoke screen for alignment with the powerful."

Feminist standpoint theorists also maintain that some of the social locations that certain individuals inhabit are better starting points than others for raising critical questions and initiating particular knowledge-creation endeavors, especially those focused on understanding power relations (Harding, 1991, 1993) or, as Dorothy Smith terms them, "Relations of ruling" (Smith, 1987, p. 3). Specifically, Harding and other standpoint theorists argue that those who occupy marginalized social locations (women, racial and ethnic minorities, working-class individuals, non-heterosexuals, or those who are transgender, for instance) have an "epistemic, scientific, and political advantage" (Harding, 2004 , p. 8) because they see the realities of inequality in a way that people occupying positions of political, economic, and social privilege do not. Many feminist activist ethnographers maintain that by seeking out the voices of those who do not typically have a dominant voice in the policy or public arena, a more whole truth can be exposed.

Not all critiques of feminist ethnography have come from the outside. While feminist researchers have long believed that ethnography is particularly well suited for feminist research because of its emphasis on interpersonal relationships and respect for and collaboration with research participants, Judith Stacey, in her heavily cited "Can There Be a Feminist Ethnography?" (1988, p. 24), argues that a "potential treacherousness" lies within this method. As she explains, "Precisely because ethnographic research depends upon human relationship, engagement, and attachment, it places research subjects at grave risk of manipulation and betrayal by the ethnographer" (ibid., p. 23). Researchers are in a very clear position of power-they typically have control over the interpretation of the data, the duration of the research, the product and presentation of the research findings, and the decision of whether they will continue to be involved in the lives of their research participants after the data collection is over. Stacey maintains that the "exploitative aspect of ethnographic 
process seem[s] unavoidable," for "the lives, loves, and tragedies that fieldwork informants share with a researcher are ultimately data, grist for the ethnographic mill, a mill that has a truly grinding power" (ibid., p. 23).

However, Davis (2013, p. 35) counters that in many cases, particularly in this era of neoliberalism, "the question is not what to omit from the feminist ethnographic production as Stacey argued, but rather, what to say when research participants want us to share their intimacies with people in positions of power" in the hopes that those individuals may be moved to help in some manner. Davis further reflects that, as a feminist activist researcher, she feels a duty to share the stories she has collected from her research participants "in the manner that they [wish] - in full detail and attributed to them" (Davis, 2013, p. 36). Further corroborating this sentiment, Anglin (2013, p. 49, note 14) maintains that her response to Stacey's question, "Can There be a Feminist Ethnography?" is decidedly "in the affirmative." As she sees it, her role as an ethnographer, activist, and feminist is to "aid in making [narratives of injustice] available" to those who might be able to facilitate change (Anglin, 2013, p. 49).

In the remainder of this article, I use the example of a "Photovoice" project that I conducted with women living in the coal-mining region of southern West Virginia to demonstrate how feminist activist ethnography can simultaneously be used for social science inquiry while also providing a venue for research participants' stories to be heard-and acted upon-by policymakers. In addition, I argue that the Photovoice method addresses some of the dilemmas of feminist ethnography regarding what details are told and whose voice does the telling (the researcher versus the research participants) through creating opportunities for participants to communicate their stories to policymakers for themselves. I examine the potential of this feminist method for empowering research participants to become more politically engaged in their communities as a form of resistance to neoliberalism's lockdown on democratic participation.

\section{The setting: The coal-mining region of Central Appalachia}

The cost externalizations of capitalism are glaringly apparent in the coalmining region of Central Appalachia, where the true price of cheap energy is externalized onto local people and their environment in the form of pollution, destruction of the land, and limited economic opportunities (Bell, 2013, 2014). In this region, more than 1 million acres of land and over 500 mountains have been destroyed by mountaintop removal coal mining (Geredien, 2009). As a result of mountaintop removal and other coal industry practices, residents must contend with devastating floods, coal slurry impoundment breaches, unsafe 
road conditions, air pollution, and ecosystem destruction (Bell, 2010, 2013; EPA, 2005; Erikson, 1976; Flood Advisory Technical Taskforce, 2002; Orem, 2006; Palmer et al., 2010; Scott et al., 2005).

One of the most alarming examples of cost externalization in Central Appalachia is the way in which the coal industry disposes of coal waste from the "cleaning" of coal. Before this fossil fuel is sent to power plants to be burned, it must be processed in order to remove non-combustible materials, such as sulfur. The coal-cleaning process that the industry chooses to use generates large quantities of liquid coal waste, also called "slurry" or "sludge." This waste product is made up of water, chemicals, and particles of coal, which contain a number of toxic metals, such as aluminum, arsenic, beryllium, cobalt, and mercury, among others. Coal waste is either stored "permanently" in huge dams on the top of surface-mined land (slurry impoundments), or it is pumped underground into abandoned mine shafts (slurry injections). Flying over southern West Virginia and eastern Kentucky, one can see that many of the enormous black impoundments - some containing billions of gallons of coal waste-are situated on mountaintops directly above small communities. The disasters of Buffalo Creek, West Virginia, in 1972 (Erickson, 1976) and Martin County, Kentucky, in 2000 (Eades, 2000; Scott et al., 2005) provide startling evidence of the tremendous damage that can ensue when one of these sludge impoundments fails. In October 2000, the Martin County impoundment spilled 250 million gallons of sludge (20 times greater than the Exxon Valdez oil spill) and polluted more than 70 miles of West Virginia and Kentucky waterways, killing wildlife, decimating habitats, and destroying homes. The community of Buffalo Creek suffered an even more devastating fate on the morning of February 26, 1972, when a torrent of black sludge water ripped through the hollow, killing 125 people and leaving thousands homeless (Erikson, 1976). These two ruinous events are not the only slurry impoundment failures that have occurred; many smaller impoundment breaches take place regularly throughout coal-affected regions and often go unreported in news media outlets. In 2000, 45 slurry impoundments in West Virginia were considered to be at high risk for failure, and 32 were at moderate risk (Eades, 2000).

Underground slurry injections create additional burdens for individuals living in close proximity to these operations. Residents of some communities in Mingo, Boone, and Logan counties in southern West Virginia have found that their well water is contaminated with coal waste leached from underground slurry injection sites (Bell, 2013). Many of the people in these communities at first did not realize that the discolored water was actually coal waste - they were told they either just had iron in their water or that dirt was getting through their 
filters. So people bought better water filters and continued drinking, cooking with, and bathing in this contaminated water for many years - until they and their families became ill.

There are well-documented medical disorders that result from organic coal compounds in drinking water, most notably diseases of the kidneys and urinary tract, such as Balken endemic nephropathy, which causes end-stage renal failure and has been linked to cancers of the renal pelvis and upper urinary tract (Orem, 2006). Many of the individuals whose well water is polluted with coal waste have reported suffering a wide range of illnesses, including liver cancer, kidney cancer, brain cancer, skin disorders, gall stones, colitis, painful urination, chronic diarrhea, and organ failure (Duhigg, 2009a; Wells, 2006).

Former top Mine Safety and Health Administration safety trainer Jack Spadaro maintains that the type of coal cleaning that generates a need for coal slurry impoundments and slurry injections is not necessary, as there are "other technologies, such as dry filter press systems." However, he asserts that the coal industry uses these methods because it "saves a dollar a ton in processing" (Stockman, 2006, pp. 6-7). Thus, while there are other methods of coal cleaning and waste disposal that would be safer for local residents, the coal industry in Central Appalachia chooses not to use these more expensive methods, opting instead to externalize the costs onto the surrounding people and environment.

\section{Photovoice as feminist activist ethnography}

As part of a larger study (Bell, 2010) examining the barriers to local participation in the Central Appalachian environmental justice movement, in 2008 and 2009 I undertook an eight-month Photovoice project with women living in five coalmining communities in southern West Virginia. ${ }^{3}$ The outcomes of this project, many of which were tangential to my own academic research questions and goals, reveal the way that feminist ethnography can be used as a tool to counter the lobbying efforts of the polluter-industrial complex, bringing the voices of unheard citizens to the policy arena.

First conceptualized in the public health literature by Wang and colleagues in the mid-1990s, Photovoice employs participant-produced photography and narratives as a means of giving voice to and facilitating "empowerment education" among marginalized persons or groups (Wang \& Burris, 1994; Wang et al., 1998). While others have used modified versions of this method and have still called it Photovoice, the original conceptualization of the process is explicitly feminist (Wang \& Redwood-Jones, 2001). Through Photovoice,

3 The project reported here is distinct from the Photovoice project discussed in Bell (2008), which was an earlier, smaller project that I initiated five years earlier in only one coal-mining community. 
individuals receive cameras to take pictures that represent important aspects of their lives and communities. Participants attend regular group reflection meetings to share their images, identify common themes, build social bonds with other group members, and discuss and examine the underlying issues represented in their images. After discussing their photographs, participants write short narratives to accompany their pictures, creating "photostories." Often, Photovoice groups will hold community exhibits, presentations, and participate in other actions as part of their projects. Photovoice has been used in many places throughout the world to provide a mechanism for individuals to become their own documentary photographers, empowering them to make decisions about how their lives and communities should be represented, instead of allowing outside journalists to make those decisions for them. Photovoice has also been used extensively in the field of public health as a health promotion strategy (Catalani \& Minkler, 2009).

While Photovoice has primarily been conceptualized as a type of participatory action research, I maintain that it can also be a powerful example of feminist activist ethnography. As noted above, ethnography is a combination of methods that are used to understand the social world-from the perspective of those who are the subjects of our research - through personal engagement with our research participants (Hobbs, 2006). At the very least, Photovoice includes participant observation and the creation of participant-produced photography and narratives, but it often also includes other methods characteristic of ethnography, such as interviews and focus groups. Furthermore, what makes Photovoice a feminist method is its focus on marginalized individuals as the participants, and their everyday experiences as the subject matter of the photostories they create. It should be no surprise that Photovoice can be both participatory action research and feminist activist ethnography, as feminisms have long "informed and grounded action research," despite the fact that many participatory action researchers are unaware of the connection (Maguire, 2001, p. 59).

\section{Photovoice in five coal-affected communities}

During the summer of 2008, I began recruiting participants in five coalmining communities for an eight-month Photovoice project in southern West Virginia. Across these five communities, a total of 54 local women $^{4}$ signed up for the project, 47 of whom had no prior involvement in environmental justice activism and seven of whom were somehow associated with at least one local environmental justice organization working to hold the coal industry responsible for coal-related problems.

4 Some women did drop out over the course of the eight months, however. A total of 40 women created at least one "photostory" during the project, and 35 completed the project. 
During the orientation, I gave all the participants digital cameras and asked them to take pictures to "tell the story" of their communities, emphasizing that this story could include positive aspects of their lives and also the problems they and their neighbors face. I facilitated meetings every three weeks in each of the five communities throughout the eight months, providing an opportunity for the women to share their photographs with each other, identify themes or issues that were common among the photos that were shared, create "photostories" (photographs with written narratives), and openly talk about potential solutions to community problems they discussed. In addition to the local meetings, I also organized two regional Photovoice gatherings during the project so that the women from all five communities had the opportunity to meet each other and share their photostories with women from the other communities.

Feminist critiques of fieldwork have pointed to the power imbalances that exist in both the design of research and in the research setting. Feminist ethnographic methods, such as Photovoice, attempt to challenge these power dynamics by viewing research participants not as "subjects" but as partners in the study and co-creators of the design, implementation, and benefits of the research. Thus, while in my project I sought to study the social processes taking place during the course of the project in order to better understand the barriers to environmental justice activism, the participants had power over the ultimate outcomes of the project itself. They decided what to photograph, what aspects of life to write about, and which photostories to include in the public exhibits and presentations.

Because they decided what to photograph, some of the women did not focus on coal-related issues at all. Many decided to use their photographs to dispel negative stereotypes about the region, showcasing the beauty of southern West Virginia's mountains, creeks, and wildlife. Others chose to document important cultural traditions and the rich history of the area through their photostories, such as Figure 1, titled "Ginseng." 


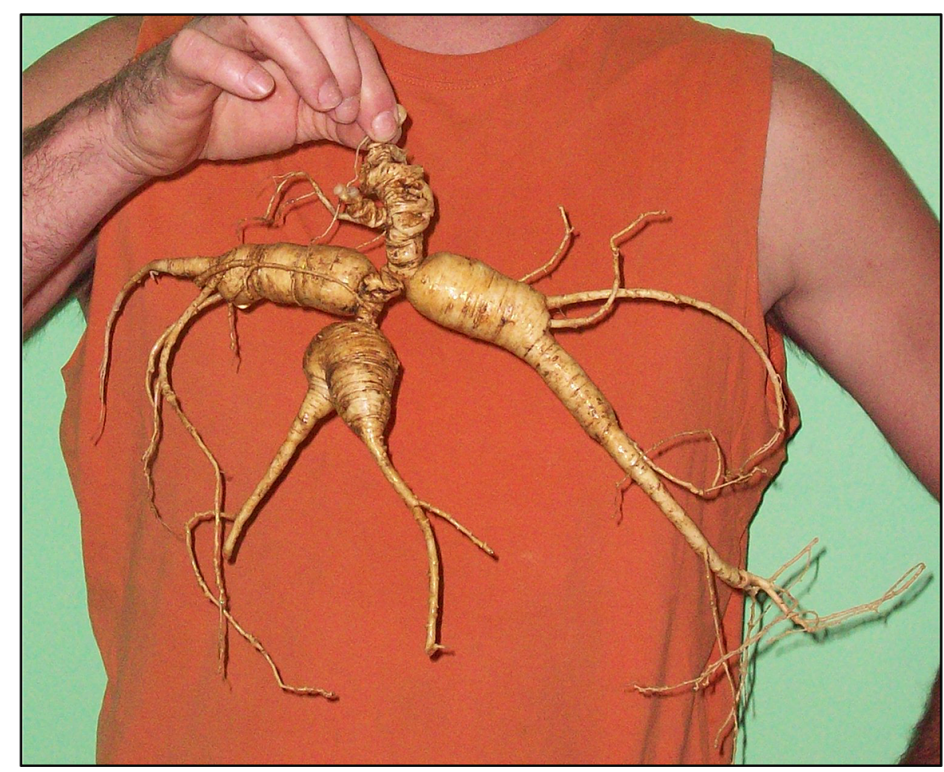

“Ginseng"

Ginseng grows wild in the hills of West Virginia. This piece of ginseng was found in [my community]. It weighed 7 ounces. It might not sound like much, but it isn't something one can find very often....more like once in a lifetime, if you're fortunate. In 2007 , one could sell ginseng for around $\$ 800.00$ per pound. A piece this size would sell for well over $\$ 1000.00$. There is a difference between wild ginseng and cultivated ginseng. It was estimated that this particular piece was over 100 years old!

\section{Figure 1. Example of a photostory about cultural traditions in West Virginia}

Source: Southern West Virginia Photovoice Project.

In addition to positive photostories, most of the women also used their photographs and words to reveal problems that they perceived in their communities. It was through these problem photostories that the power of feminist ethnography for reaching policymakers became apparent. Those who chose to use Photovoice in this way focused on a number of different issues, such as dilapidated and dangerous roads or the overwhelming amount of trash littering the roadsides and creek banks. Figure 2 is one example. It is called "Please Pass the Bottle Bill!" and advocates for the West Virginia legislature to pass a bottle deposit law. 


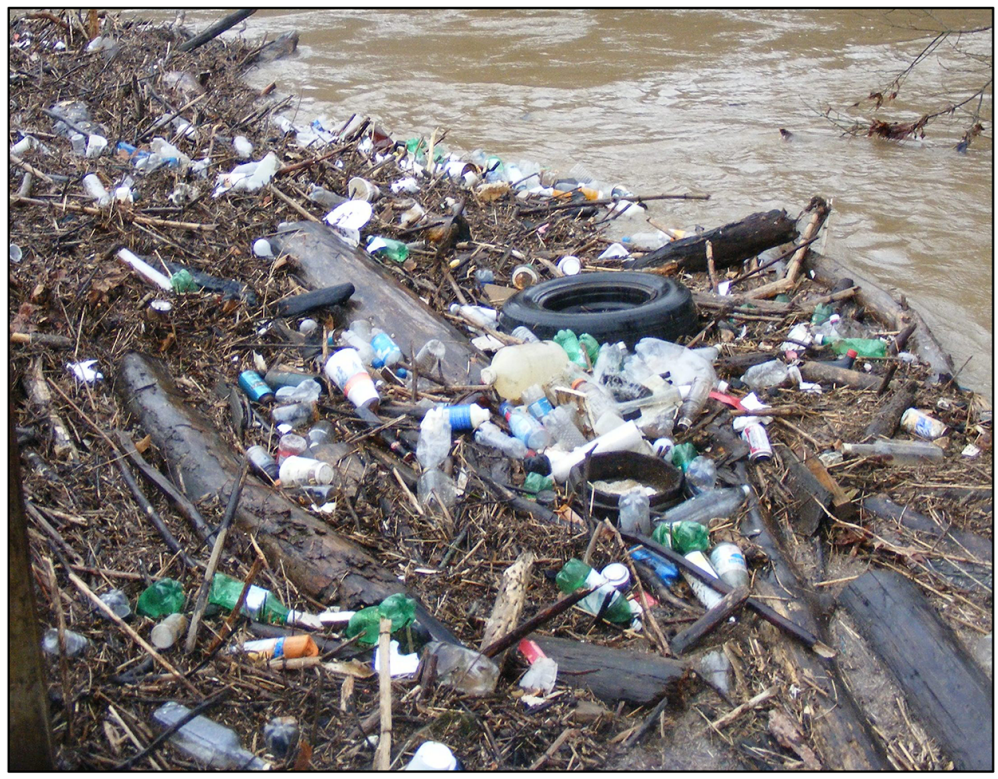

"Please Pass the Bottle Bill!"

This picture was taken [in my community] after a rain. As you can see, trash piles up against our bridges almost anytime it rains. Look at all those bottles! The biggest part of the trash we see piled up by our bridges is pop bottles and water bottles. This is really nasty to look at, and all this trash is also very hard on the wildlife in our area. If we had a bottle deposit in our state, a lot of this wouldn't be here. I would really like to see our state pass the Bottle Bill this year.

\section{Figure 2. Example of a problem photostory}

Source: Southern West Virginia Photovoice Project.

One of the major problems that became a focal area for many of the women was water contamination. Figure 3 reveals one participant's worries related to coal slurry injection sites behind her home. 


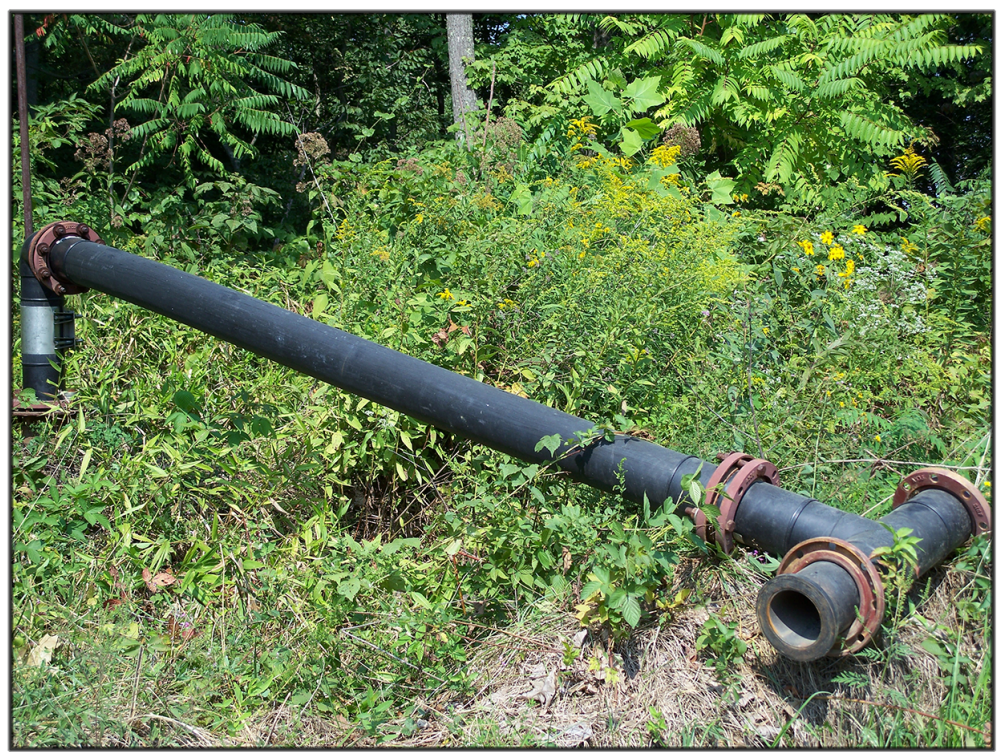

\section{“Coal Slurry Injection Site”}

This pipe is where the coal companies injected coal slurry (waste) into an old underground coal mine for storage. There are many sites like this throughout the mountains, and no one knows they are there unless they happen upon them while four-wheeling. This site is directly above my home. If it ever breaks loose, the damage will be devastating. No one has ever contacted us to inform us that this slurry injection was taking place so close to our house.

\section{Figure 3. Example of a slurry injection site photostory}

Source: Southern West Virginia Photovoice Project.

As the women created photostories documenting the problems in their communities, I encouraged them to write, call, and even meet with their state legislators to discuss the issues. Many of the Photovoice women communicated with their legislators for the very first time through this project, mailing their representatives printed copies of their "problem" photostories or calling them directly. Three even traveled to the state capitol to meet with their legislators in person, taking photostories and video footage of their community's potholestricken roads and water contamination to share. In addition, I helped the Photovoice women organize public exhibits and presentations of their photostories in each of the five communities and put together a regional exhibit in the capital city of Charleston. The women invited local politicians and 
legislators to these exhibits and presentations, which was another opportunity to communicate with their elected officials. Four of the five community exhibits had at least one state legislator in attendance. In addition, three local newspapers and one state newspaper covered the content of the Photovoice exhibits, and West Virginia Public Radio ran a four-minute story about the project (including audio from one of the community exhibits). We also created a legislative "issue booklet" of photostories depicting coal-related water contamination, made a website, and self-published a book of photostories that has become part of the collections of a few rural libraries in southern West Virginia. At the end of the project, the women kept all of the photostory boards so that they could continue to organize and hold exhibits of their work throughout their communities.

\section{Photovoice outcomes in Prenter, West Virginia}

Less than a year before the Photovoice project started, residents of one of the communities in the project became concerned about possible contamination problems in their well water. One of the local environmental justice organizations held a community meeting to provide a forum for residents to discuss their worries about their discolored and foul-smelling water. Resident Maria Lambert and her family attended this meeting. They, like the others in attendance, began to realize that what they thought was just a problem with their own water was actually a bigger community issue. As Maria told me in an interview for my (2013) book,

Everybody was showing [samples of] their water. Different people stood up and told about their water and told about what they believed was happening, and told about the different illnesses - the brain tumors, the gall bladder problems, stomach problems, children's teeth falling out, and all of these things.

As she listened to her neighbors, Maria started to realize the similarities between their stories and what had been happening in her own family:

[I]t's like my whole life [was] flashing before my eyes, because my children had lost their teeth [from decay before breaking through the gums], my parents had had cancer, we'd had our gall bladders removed, and all of these things was, it's just like, oh no, it's not just us - it's the whole community, and we're not even blood related. There was Jennifer Massey, who had lost her brother to a brain tumor; Kathy Weikle who had a pituitary tumor; Terry Keith who has the triplets and another grandchild who has to bathe in the water, and they were having a rash and everything. They were having to mix their formula with the water and didn't realize it was bad. Oh gosh, let's see. Several people had kidney problems in their family. There's been two kidney transplants- 
one was a small child and one was an older gentleman - in the past four or five years. People dying from kidney disease, kidney dialysis patients. My mother had to have a third of her lung removed from lung cancer - it wasn't in the bronchial tubes, it was in the fatty part of the lung, the tissuey part of the lung. And then my father come through thyroid cancer. And my husband and I both have had major stomach problems. (Bell, 2013, p. 72)

The weekend after the community meeting, Maria was hospitalized for intestinal bleeding. Below, she describes the anger she felt when she discovered that the well water was the cause of her health problems.

All summer long I had been on some medication, and my white blood [cell] count had dropped down to 2.5, and that is not good. They wanted me to go off of some of my medication to see if it could be that that was causing it. And I thought, "Well, since I'm going off of medication, I'm just going to go ahead and try to lose some of this weight," because I weighed over two hundred pounds. I lost fifty pounds by drinking water all summer long - our water - the water that we should not have been drinking. They tell you, "Drink lots of water," you know. So when I found out that what I thought was supposed to be a good thing [made me sick], I got so mad. It was just like an inferno inside of me that was just busting to get out. I was just really, really mad. And about the time I would think that I was going to get over it, I'd get mad all over again.

... [P]eople are suffering and it's not right for people in power to take advantage of everyday working, taxpaying, breathing citizens. They're taking away from us and trying to make people believe that they're giving to us. They have made people believe that for a hundred years, or more - even from the beginning of time. People in power have always abused their power. (Bell, 2013, pp. 78-79)

The residents learned that the well-water contamination was the result of an underground coal slurry injection site. The coal waste had leached out of the storage chambers (which were abandoned underground coal mines) into the water table, polluting all of the wells in the community. Soon after this initial community meeting, Maria became involved with a campaign to bring clean water to Prenter. The group's immediate concern was to raise money for emergency water deliveries to the homes of residents living in the vicinity. Their ultimate goal was to raise enough money and awareness so that the municipal water line would be extended up the entire hollow in order for residents to have permanent access to clean water. 
The Photovoice project began a few months after the water efforts in this community were under way. Maria joined a local Photovoice group, and she decided to use her photostories to help draw attention to the water contamination problems that she and other residents were experiencing (see Figure 4).

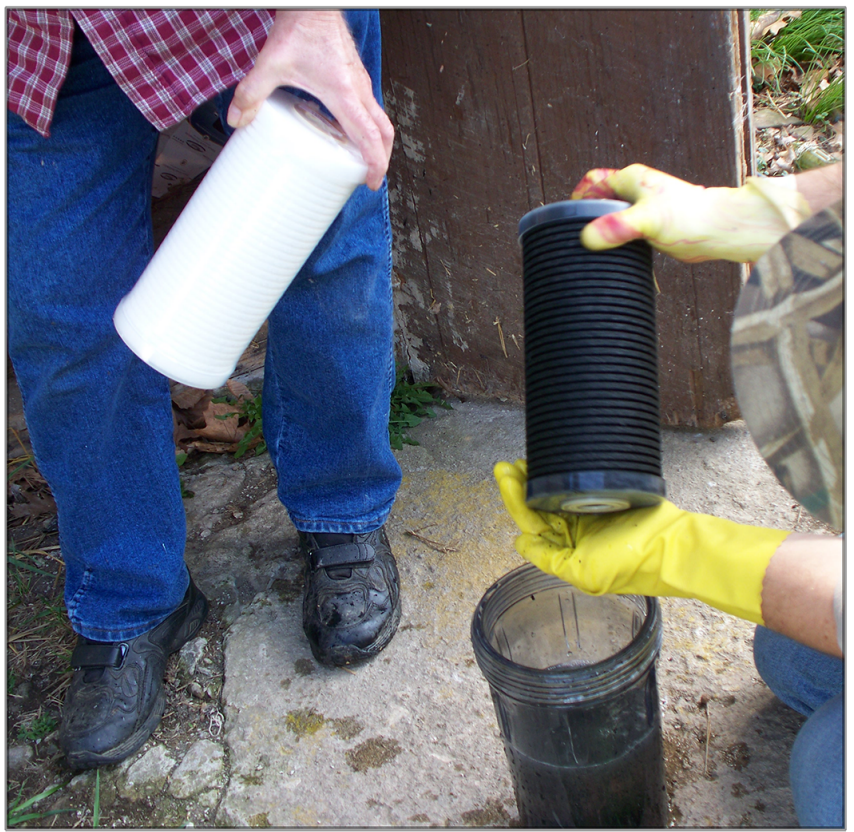

"The Changing of the Water Filter"

This photo shows what a new water filter should look like (white one) and after only three months (black one), it has become unthinkably black from something lurking in the well. My Dad says it looks like pure coal slurry water -- he should know, as he worked at a coal tipple for many years and saw first-hand what it looked and smelled like.

\section{Figure 4. Example of a water contamination photostory}

Source: Southern West Virginia Photovoice Project.

In addition to their inclusion in the community exhibits that we held, the photostories that Maria created, along with other participants' water contamination photostories, were used to create a full-color, 20-photostory legislative booklet to be used during the 2009 legislative session. The Photovoice women and a community group called the Sludge Safety Project distributed these booklets to West Virginia legislators and used them along with 
the enlarged photostory boards in their efforts to educate community leaders, policymakers, and local citizens about the problems with coal slurry injections and impoundments.

Due to the hard work of Maria and the various community groups working for clean water in Prenter, including the Sludge Safety Project, the Prenter Water Fund, Coal River Mountain Watch, and Ohio Valley Environmental Coalition, this community did raise enough money for an emergency water supply, and they eventually received a city block grant to have water service extended into Prenter Hollow. In addition, progress was made toward the goal of banning the practice of underground slurry injections. During the groundbreaking ceremony for the waterline in August 2009, Senator Ron Stollings announced that the West Virginia Department of Environmental Protection would be placing a moratorium on all new permits for coal slurry injection sites. ${ }^{5}$ As reported in the Coal Valley News, Stollings specifically cited Maria's photostories as a reason for his commitment to stop new underground coal slurry injections:

"There are some health issues in this community," the Senator and local physician said. "There will be no more new slurry injections from here on out," Stollings said to a round of applause. Stollings praised the work of Prenter resident Maria Lambert, whose photo essays helped give a visual voice to the problems plaguing the area. "I appreciate that grassroots approach and it goes to show that the old adage, the squeaky wheel gets the grease, is correct," he said. (Newman, 2009)

While this Photovoice project was just one small community-based action among the tremendous number of communications legislators receive from industry lobbyists, it does demonstrate how effective this method can be for providing a point of connection between the grassroots community and policy-makers. If making these connections between our research subjects and the policy arena were to become normative within social science research, the outcomes could be significant.

\section{Photovoice as "empowerment education"}

While the awareness that the photostories helped bring to the water contamination problems in Prenter was one of the more profound outcomes from the project, there were a number of other less politically contentious, but still positive, results in the other communities. As I describe elsewhere, most of the women who created coal-critical photostories, even those who chose to display them publicly, were not comfortable moving from critique of the

5 However, activists are still pushing for a moratorium on permit renewals and modifications for current slurry injection sites. 
coal industry to actually taking action against its harmful practices through activism (Bell, 2010). I found numerous social forces at play preventing these women from becoming involved more formally in the environmental justice movement, two of the most significant being the power of the local elite, who were able to exert great pressure within their small communities to stifle residents' willingness to speak out against the coal industry, and, secondly, the changing face of the environmental justice movement, which has made potential local recruits less likely to view the movement as being compatible with their own personal identities (Bell, 2010). Despite the fact that only five of the participants who started the project as "non-activists" became formally involved in the environmental justice movement during the project, 17 of the non-activist participants chose explicitly coal-critical or vaguely coal-critical photostories for inclusion in the public exhibits and the Photovoice website. Thus, it appears that Photovoice provided a number of the participants who were not comfortable with activism per se a more socially "safe" opportunity for expressing public dissent against the practices of the coal industry.

While most of the women were not comfortable becoming involved in formalized activist activities, all of the groups advocated for certain changes and ideas for improvement in their communities. Less politically contentious issues, such as poor road conditions or litter, were common advocacy issues among the Photovoice groups. These were issues that did not challenge the power structure but still gave participants the satisfaction of taking action. One example of such an issue was the pothole-stricken condition of the roads in one of the Photovoice communities. During a meeting at which I led the participants through a process of prioritizing the community problems they had identified through their photostories, the problem of dangerous road conditions, caused by overweight coal trucks, rose to the top of the list of concerns. Inspired by discussions that took place at our regional Photovoice meeting two weeks earlier, Barbara $^{6}$ asked, "Can we get an appointment and just talk to [a legislator]? Let's make a difference - I'm ready!" All of the women in attendance responded enthusiastically to the idea of sharing their concerns with lawmakers, so I provided the women with the phone numbers for all of their state senators and delegates. The women then decided who would photograph different problem areas on the roads in order to create a series of photostories revealing the poor road conditions in their part of the county. At our next meeting, the participants shared five photostories they had created documenting the cracking, potholed roads, as well as one video of the treacherous driving conditions. Barbara volunteered to set up appointments with their two state legislators and was surprised by how easily she was able to schedule these appointments.

6 Barbara is a pseudonym. 
Barbara, Brandy, ${ }^{7}$ and Brandy's three-year-old son met me at the state capitol on the day of their appointments, and we went together to their legislators' offices. The photostories, video footage, and Barbara and Brandy's pointed descriptions seemed to reach the two policymakers. Both legislators promised to work on having the roads in their community moved up on the list of repaving projects, as those stretches of road had not been fully repaved in more than 25 years. During our visit, both of the legislators made phone calls to the Department of Highways to request immediate road patching as a temporary fix. Just a few hours later, one of the Photovoice group members who did not go to the capitol saw - and photographed - the Department of Highways patching the problem areas about which Barbara and Brandy had complained! In the months that followed, Barbara regularly checked in with her legislators via phone about the progress being made toward full repaving of their roads.

In addition to the outcomes I have already discussed, the Photovoice project also helped bring about a number of other positive changes in the communities, including the installation of a guard rail on a dangerous curve above a deep ravine; the removal of a dangerous, cracking rock overhang above a narrow stretch of road leading into one of the communities; the repair and reopening of a beloved community pool; the replacement of two dangerous bridges; community-initiated clean-up days; and an increase in civic engagement among many of the Photovoice participants.

While Photovoice was not a pathway to activism among most of the women in the project, it did teach them how to communicate with their legislators and showed them that their opinions matter. One of the profound strengths of Photovoice is the fact that many voices and issues can be articulated, and that participants come to see themselves as holding the power and ability to communicate with policymakers and others with political influence. While participant empowerment is difficult to quantify, it is extremely important. As Wang and colleagues have articulated, the Photovoice process often engenders "empowerment education" among participants (Wang \& Burris, 1994; Wang et al., 1998). The outcomes of Photovoice reach beyond simply drawing attention to problems experienced by individual participants. Photovoice also holds the potential to foster a change in the perceptions of participants from noninfluential to influential, helping them to see themselves "as actors in the public arena instead of objects of it" (Bell, 2008, p. 41). The fact that many of the Photovoice participants made their first contacts with legislators through this project is not insignificant; a number of the women did not previously know how to access (or even that they could access) their elected officials.

7 Brandy is a pseudonym. 
Many of the participants had positive encounters with their legislators, some even receiving personal phone calls asking for more information about their concerns, and this both surprised and inspired them. Reflecting on her efforts advocating for bottle deposit legislation during the Photovoice project, one participant revealed,

It made me think that it was possible. You know? A lot of times whenever [I] get a big dream or idea in [my] head, I've never really thought real positive about it. It gave me a positive outlook on it anyway, you know, instead of being such a downer.

Another participant expressed similar feelings of increased efficacy after sharing her photostories with community leaders and the general public at her group's community presentation and exhibit:

That was somethin' - made me feel like I was on top of the world! Like I could make a difference. 'Cause I didn't think I could do it, because I'm not a talker.

Even after the project ended, a number of the women continued their community work, organizing community clean-ups, calling legislators, and speaking up about problems in their communities. The Photovoice project provided a mechanism for local residents to communicate with policymakers about needs that were going unmet and about the ways in which corporate polluters were affecting their communities. The power of Photovoice as a communication strategy lies in its authenticity. The photographs and narratives are created by people who are directly experiencing these issues, not by paid employees of an advocacy or special interest group.

\section{Discussion and conclusion: Bridging two social worlds}

While feminist activist ethnography provides many important opportunities for scholar-activists, it is not without its challenges. As Francesca Cancian (1993, p. 92) notes, within academia, "activist research often conflicts with academic standards" because while activist research "aims at challenging inequality by empowering the powerless, exposing the inequities of the status quo, and promoting social changes that equalize the distribution of resources," more traditional academic research "aims at increasing knowledge about questions that are theoretically or socially significant." Activist research is primarily "'for' relatively powerless groups and often involves close social ties and cooperation with these groups," while academic research is "primarily 'for' colleagues," involving "close ties with faculty and students, and emotional detachment from 
the people being studied" (Cancian, 1993, p. 92). Thus, scholars who have a commitment to doing activist research, but who also want to have successful academic careers, must often find a way to "bridge two conflicting social worlds" (Cancian, 1993, p. 92).

Bridging these conflicting social worlds does pose some challenges. As I mentioned previously, the Photovoice project I conducted was part of a larger study (Bell, 2010) aimed at unraveling the various social factors contributing to the relatively low levels of local participation in the environmental justice movement that has been working to hold the coal industry accountable for the many social, environmental, and economic problems it is causing in Central Appalachia. My motivation for initiating a Photovoice project in southern West Virginia was action-oriented-I hoped such a project would draw attention to the hidden injustices taking place in coal-affected communities in southern West Virginia, while also creating a project that was empowering to the participants and their communities. However, it simply would not have been professionally possible at that stage in my career to devote such a great deal of time and so many resources to a project like this had I not also been able to find a way to make it useful to larger theoretical questions I was investigating about the barriers to environmental justice activism. Thus, while my research participants had complete control over what they chose to photograph, what they wrote about those photographs, which of their photostories would be displayed publicly, and what community projects were inspired through the process, I was also collecting data on the decisions they made. Specifically, I was collecting data on who created photostories that were critical of the coal industry, who chose to display their coal-critical photostories in the public exhibits, who took that difficult step into activism to hold the coal industry accountable for the problems it was causing, and-importantly — who did not. My participant observation data and follow-up interviews focused on the social factors within the Photovoice groups and larger communities that led to participants' willingness or unwillingness to speak critically about the coal industry.

Thus, there were questions within this larger academic research project that were driven by my own research agenda and not that of my research participants. It is important to acknowledge that this is a modification to the "pure" form of participatory action research, wherein the research participants drive all aspects of the study, including the research questions, data collection, and dissemination of the results. My choice to conduct two simultaneous projects (one action-oriented, one academic) with the five Photovoice groups made it possible for me to meet both professional and community interests through the same project, something that may not have been possible otherwise. Indeed, as Cancian (1993) found, this is a strategy to which many other scholar-activists turn. Retaining some control over the research process, and thus modifying 
the exclusively collaborative nature of participatory action research, is the approach that all of the scholar-activists Cancian interviewed described using in order to make their activist projects compatible with academic expectations, namely generating peer-reviewed publications. Creating two agendas within the same project (one that the research participants control and one that the researcher controls) is one way to avoid the bind of choosing between the two social worlds of activism and academia. It does, however, also mean that the cautions that Stacey (1988) articulates about feminist ethnography still hold. As scholar-activists using feminist ethnography for dual purposes, we must carefully consider the consequences of our own research agenda and ensure that it does not undermine our research participants' goals for the communitydriven portion of the project. ${ }^{8}$

My aim here has been to suggest that, contrary to mainstream beliefs in the academy, social scientists do not need to choose between being an activist and being a scholar - both needs can be met through the same project, and the richness and depth of data that can be collected through feminist ethnography in particular allows for the creation of more than one type of "product." There is room for both theory building and advocacy within the academy. Feminist ethnographic methods, like Photovoice, hold the potential to provide a path through the overgrown landscape between disenfranchised groups and policymakers. As social scientists, our research often positions us in such a way that we could serve as links between the people we study and policy-makers, providing an avenue for exposing the concerns of unheard individuals through bringing their stories forward, or - as in the case of Photovoice - by facilitating a process by which research participants may bring their own stories forward.

\section{Acknowledgments}

I am very grateful to the grant agencies and organizations that funded and provided other resources to make the Southern West Virginia Photovoice project possible: The Greater Kanawha Valley Foundation, the Appalachian Regional Commission/West Virginia Development Office Flex-E Grant, the American Sociological Association's Spivack Program in Applied Social Research and Social Policy, the Center for the Study of Women in Society at the University of Oregon (UO), the UO Department of Sociology's Wasby-Johnson Fellowship,

8 This is not to say that we will be able to anticipate all tensions that may emerge, however. In my Photovoice project, for instance, difficulties arose in one of the groups when certain powerful individuals in the wider community felt that the project was too critical of the coal industry. Some participants of the Photovoice group began to silence coal-critical discussions during our meetings due to their worries about the way the project was being perceived by those powerful individuals. The group members wanted to counter those perceptions about the project, and I felt it important to respect their wishes. As a result, I worked with them to amplify the non-coal-related issues, concerns, and ideas for change that they identified through the project in their public presentation and in their community exhibit. 
the UO Doctoral Dissertation Fellowship, the Ohio Valley Environmental Coalition, Cabin Creek Health Systems, Photographic Production Services, and the Clay Center for the Arts and Sciences. I am also grateful to Dána-Ain Davis and Christa Craven for organizing a panel on Feminist Activist Ethnography and Neoliberalism at the 2010 American Anthropological Association Annual Meeting. Participating on this panel is where the seeds of this article were planted. I would also like to thank the anonymous reviewers for their invaluable feedback and suggestions. Finally, I thank the Photovoice participants for being part of this project and for sharing their stories, photographic creativity, and love for their communities with me.

\section{References}

Agger, B. (2000). Public sociology: From social facts to literary acts. Rowman \& Littlefield Publishers.

Anglin, M. K. (2013). Learning social justice and activist ethnography from women with breast cancer. In C. Craven \& D.-A. Davis (Eds.), Feminist activist ethnography: Counterpoints to neoliberalism in North America (pp. 39-52). Lanham, MD: Lexington Books.

Beckel, M. (2011, March 10). Lobbyists aggressively targeted democrats' top priorities during Barack Obama's first two years. OpenSecretsblog: Investigating money in politics. Retrieved from http://www.opensecrets. org/news/2011/03/lobbyists-aggressively-targeted-dem-legislation.html

Beder, S. (1998). Public relations' role in manufacturing artificial grass roots coalitions. Public Relations Quarterly, 43(2), 21-23.

Bell, S. E. (2008). Photovoice as a strategy for community organizing in the Appalachian coalfields. Journal of Appalachian Studies, 14, 34-48.

Bell, S. E. (2010). Fighting king coal: The barriers to grassroots environmental justice movement participation in Central Appalachia (Unpublished doctoral dissertation). Department of Sociology, University of Oregon.

Bell, S. E. (2013). Our roots run deep as ironweed: Appalachian women and the fight for environmental justice. Chicago: University of Illinois Press.

Bell, S. E. (2014). "Sacrificed so others can live conveniently": Social inequality, environmental injustice, and the energy sacrifice zone of Central Appalachia. In C. M. Renzetti \& R. Kennedy Bergen (Eds.), Understanding diversity: Celebrating difference, challenging inequality (pp. 261-274). Boston, MA: Allyn and Bacon. 
Bell, S. E., \& York, R. (2010). Community economic identity: The coal industry and ideology construction in West Virginia. Rural Sociology, 75, 111-143.

Bickham-Mendez, J. (2008). Globalizing scholar activism: Opportunities and dilemmas through a feminist lens. In C. Hale (Ed.), Engaging contradictions: Theory, politics, and methods of activist scholarship (pp. 136-163). Berkeley: University of California Press.

Borofsky, R. (2011). Why a public anthropology? Kailua, HI: Center for a Public Anthropology.

Boudet, H. S., \& Bell, S. E. (2014). Risks and social movements: Examining the role of communication. In H. Cho, T. Reimer \& K. McComas (Eds.), The SAGE handbook of risk communication (pp. 304-316). Thousand Oaks, CA: Sage Publications.

Brulle, R. J., \& Pellow, D. N. (2006). Environmental justice: Human health and environmental inequalities. Annual Review of Public Health, 27, 3.1-3.22.

Bullard, R. D. (1990). Dumping in Dixie: Race, class, and environmental quality. Boulder, CO: Westview Press.

Bullard, R. D., Mohai, P., Saha, R., \& Wright, B. (2007). Toxic wastes and race at twenty: 1987-2007. A report prepared for the United Church of Christ Justice \& Witness Ministries. Cleveland: United Church of Christ.

Burawoy, M. (2005). For public sociology. American Sociological Review, 70, $4-28$.

Cancian, F. M. (1993). Conflicts between activist research and academic success: Participatory research and alternative strategies. American Sociologist, 24(1), 92-106.

Čapek, S. (1993). The "environmental justice" frame: A conceptual discussion and an application. Social Problems, 40, 5-24.

Catalani, C., \& Minkler, M. (2009). Photovoice: A review of the literature in health and public health. Health \& Education Behavior. Advance online publication. doi: 10.1177/1090198109342084.

Craven, C., \& Davis, D.-A. (2013). Introduction: Feminist activist ethnography. In C. Craven \& D.-A. Davis (Eds.), Feminist activist ethnography: Counterpoints to neoliberalism in North America (pp. 1-20). Lanham, MD: Lexington Books. 
Davis, D.-A. (2013). Border crossings: Intimacy and feminist activist ethnography in the age of neoliberalism. In C. Craven \& D.-A. Davis (Eds.), Feminist activist ethnography: Counterpoints to neoliberalism in North America (pp. 23-38). Lanham, MD: Lexington Books.

Davis, D.-A., \& Craven, C. (2011). Revisiting feminist ethnography: Methods and activism at the intersection of neoliberal policy. Feminist Formations, 23, 190-208.

Duhigg, C. (2009, September 13). Clean water laws are neglected, at a cost in suffering. Toxic waters series. The New York Times.

Eades, R. (2000). Brushy fork slurry impoundment-A preliminary report. Retrieved from http://www.ohvec.org/issues/slurry_impoundments/ articles/brushy_fork.pdf.

EPA (United States Environmental Protection Agency). (2005). Mountaintop mining/valley fills in Appalachia: Final programmatic environmental impact statement. Retrieved from http://www.epa.gov/region03/mtntop/.

EPA (United States Environmental Protection Agency). (2009). Toxics release inventory: National analysis overview. Retrieved from http://www.epa.gov/ tri/tridata/tri09/nationalanalysis/overview/2009TRINAOverviewfinal.pdf.

Erikson, K. T. (1976). Everything in its path: Destruction of community in the Buffalo Creek flood. New York: Simon and Schuster.

Faber, D. (2008). Capitalizing on environmental injustice: The polluter-industrial complex in the age of globalization. Lanham, MD: Rowman \& Littlefield Publishers.

Faber, D. (2009). The unfair trade-off: Globalization and the export of ecological hazards. In L. King \& D. McCarthy (Eds.), Environmental sociology: From analysis to action. Lanham, MD: Rowman \& Littlefield Publishers.

Fals-Borda, O. (1987). The application of participatory action research in Latin America. International Sociology, 2(4), 329-347.

Feagin, J. R., \& Vera, H. 2008. Liberation sociology (2nd ed.). Boulder, CO: Paradigm Publishers.

Flood Advisory Technical Taskforce. (2002). Runoff analyses of Seng, Scrabble, and Sycamore creeks: Part I. Division of Mining and Reclamation, Department of Environmental Protection.

Foster, J. B. (2005). The treadmill of accumulation: Schnaiberg's environment and Marxian political economy. Organization \& Environment, 18(1), 7-18. 
Foster, J. B. (2009). The ecological revolution: Making peace with the planet. New York: Monthly Review Press.

Foster, J. B., Clark, B., \& York, R. (2010). The ecological rift: Capitalism's war on the earth. New York: Monthly Review Press.

Geredien, R. (2009). Assessing the extent of mountaintop removal in Appalachia: An analysis using vector data. Technical report for Appalachian Voices, Boone, NC. Retrieved from http://ilovemountains.org/reclamation-fail/ mining-extent-2009/Assessing_the_Extent_of_Mountaintop_Removal_in_ Appalachia.pdf.

Gould, K. A., Pellow, D. N., \& Schnaiberg, A. (2004). Interrogating the treadmill of production: Everything you wanted to know about the treadmill but were afraid to ask. Organization and Environment, 17(3), 296-316.

Hale, C. (Ed.). (2008). Engaging contradictions: Theory, politics, and methods of activist scholarship. Berkeley: University of California Press.

Harding, S. (1991). Whose science? Whose knowledge? Thinking from women's lives. Ithaca, NY: Cornell University Press.

Harding, S. (1993). Rethinking standpoint epistemology: What is "strong objectivity?" In L. Alcoff \& E. Potter (Eds.), Feminist epistemologies (pp. 4982). New York and London: Routledge.

Harding, S. (Ed.). (2004). The feminist standpoint theory reader. New York and London: Routledge.

Harrison, J. L. (2011). Pesticide drift and the pursuit of environmental justice. Cambridge, MA: MIT Press.

Harvey, D. (2005). A brief history of neoliberalism. Oxford: Oxford University Press.

Hay, I. (2001). Engaging lessons: Classrooms as sites of engagement in activist critical geography. International Research in Geographical and Environmental Education, 10(2), 168-173.

Hobbs, D. (2006). Ethnography. In V. Jupp (Ed.), The SAGE dictionary of social research methods (pp. 101-102). London: SAGE Publications.

Jenkins, M. (2011). What's gotten into us? Staying healthy in a toxic world. New York: Random House.

Leacock, E. (1987). Theory and ethics in applied urban anthropology. In L. Mullings (Ed.). Cities of the United States (pp. 317-336). New York: Columbia University Press. 
Maguire, P. (2001). Uneven ground: Feminism and action research. In P. Reason \& H. Bradbury (Eds.), Handbook of action research: Inquiry and practice (pp. 59-70). London: Sage Publications.

Markowitz, G., \& Rosner, D. (2002). Deceit and denial: The deadly politics of industrial pollution. Berkeley, CA: University of California Press.

Masterson-Allen, S., \& Brown, P. (1990). Public reaction to toxic waste contamination: Analysis of a social movement. International Journal of Health Services, 20(3), 485-500.

McCright, A. M., \& Dunlap, R. E. (2000). Challenging global warming as a social problem: An analysis of the conservative movement's counter-claims. Social Problems, 47(4), 499-522.

McIntyre, A. (2008). Participatory action research. Qualitative Research Methods Series. Thousand Oaks, CA: Sage Publications.

McNutt, J., \& Boland, K. (2007). Astroturf, technology and the future of community mobilization: Implications for nonprofit theory. Journal of Sociology \& Social Welfare, VVVIV, 165-178.

Newman, J. (2009, August 27). Prenter community celebrates groundbreaking on waterline. Coal Valley News.

Orem, W. H. (2006). Coal slurry: Geochemistry and impacts on human health and environmental quality. U.S. Geological Survey, Eastern Energy Resources Team. PowerPoint presentation to the Coal Slurry Legislative Subcommittee of the Senate Judiciary Committee, West Virginia Legislature, November 15.

Oreskes, N., \& Conway, E. M. (2010). Merchants of doubt: How a handful of scientists obscured the truth on issues from tobacco smoke to global warming. New York: Bloomsbury Press.

Palmer, M. A., Bernhardt, E. S., Schlesinger, W. H., Eshleman, K. N., FoufoulaGeorgiou, E., Hendryx, M. S., ... Wilcock, P. R. (2010). Mountaintop mining consequences. Science, 327, 148-149.

Pellow, D. N. (2004). Garbage wars: The struggle for environmental justice in Chicago. Cambridge, MA: The MIT Press.

Pellow, D. N. (2007). Resisting global toxics: Transnational movements for environmental justice. Cambridge, MA: The MIT Press.

Reid, H., \& Taylor, B. (2010). Recovering the commons: Democracy, place, and global justice. Urbana and Chicago: University of Illinois Press. 
Schnaiberg, A. (1980). The environment: From surplus to scarcity. New York: Oxford University Press.

Scott, S. L., McSpirit, S., Hardesty, S., \& Welch, R. (2005). Post disaster interviews with Martin County citizens: "Gray clouds" of blame and distrust. Journal of Appalachian Studies, 11(1\&2), 7-28.

Smith, B. E. (2011, April 14). Transforming places: Towards a global politics of Appalachia. Place Matters Lecture, Appalachian Studies Lecture Series, University of Kentucky.

Smith, B. E. (2014). Another place is possible? Labor geography, spatial dispossession, and gendered resistance in Central Appalachia. Annals of the Association of American Geographers, XX(X), 1-14.

Smith, B. E., \& Fisher, S. L. (2012). Transformations in place. In S. L. Fisher \& B. E. Smith (Eds.), Transforming place: Lessons from Appalachia (pp. 267-201). Urbana, Chicago, and Springfield: University of Illinois Press.

Smith, D. E. (1987). The everyday world as problematic: A feminist sociology. Boston: Northeastern University Press.

Stacey, J. (1988). Can there be a feminist ethnography? Women's Studies International Forum, 11(1), 21-27.

Stanley, L. (Ed.). (1990). Feminist praxis: Research, theory and epistemology in feminist sociology. Abingdon: Routledge.

Stockman, V. (2006, Spring). Jack Spadaro: Former top MSHA safety trainer fights the tragic consequences of mountaintop removal mining. Appalachian Voices.

Sweezy, P. M. (1989). Capitalism and the environment. Monthly Review, 41(2), $1-10$.

Switzer, J. V. (1997). Green backlash: The history and politics of environmental opposition in the U.S. Boulder, CO: Lynne Rienner Publishers.

Tandon, R. (1981). Participatory research in the empowerment of people. Convergence: An International Journal of Adult Education, 14(3), 20-27.

Wang, C., \& Burris, M. A. (1994). Empowerment through photo novella: Portraits of participation. Health Education Quarterly, 21(2), 171-186.

Wang, C., \& Redwood-Jones, Y. (2001). Photovoice ethics: Perspectives from Flint Photovoice. Health Education and Behavior, 28(5), 560-572. 
Wang, C., Yi, W. K., Tao, Z. W., \& Carorano, K. (1998). Photovoice as a participatory health promotion strategy. Health Promotion International, 13(1), 75-86.

Wells, L. A. (2006, August 13). Lawsuits muddy water project. Appalachian News-Express. Retrieved from http://ohvec.org/newsletters/woc_2006_09/ article_03.html. 
This text taken from Human Ecology Review Volume 21, Number 1, 2015, published 2015 by ANU Press, The Australian National University, Canberra, Australia. 